\title{
Review on Estimation of Crop Water Requirement, Irrigation Frequency and Water Use Efficiency of Cabbage Production
}

\author{
Siraj Beshir \\ Department of Natural Resource Management, College of Agriculture and Natural Resources, Madda Walabu Univeraity, \\ Bale Robe, Ethiopia \\ Email: sirajnrm@gmail.com
}

How to cite this paper: Beshir, S. (2017) Review on Estimation of Crop Water Requirement, Irrigation Frequency and Water Use Efficiency of Cabbage Production. Journal of Geoscience and Environment Protection, 5, 59-69.

https://doi.org/10.4236/gep.2017.57007

Received: July 11, 2016

Accepted: July 11, 2017

Published: July 14, 2017

Copyright $\odot 2017$ by author and Scientific Research Publishing Inc. This work is licensed under the Creative Commons Attribution International License (CC BY 4.0).

http://creativecommons.org/licenses/by/4.0/

\begin{abstract}
Water is the major limiting factor for crop production. A lot of water resources have been exploited for irrigation purpose. Therefore, the objective of this review paper was to collect information on cabbage water requirement, irrigation scheduling and water use efficiency by triangulating different literatures on the topic. Nowadays on worldwide there is a water-shortage, accordingly it is necessary to adopt water saving agriculture as a counter measure as well as efficient use of irrigation water is becoming increasingly important. In growing crop, irrigation scheduling is a critical management input to ensure optimum soil moisture status for proper plant growth and development as well as for optimum yield, water use efficiency and economic benefits. Thus according reviewed literatures on average twice a week irrigation scheduling and $2.57-5.81 \mathrm{~mm} /$ day of crop water requirement is more visible for cabbage production. In addition, climate models were reviewed in detail in this paper CROPWAT 8.0 and DSSAT reproduce acceptably the unimodal and bimodal shapes of the annual variation of rainfall and temperature respectively; there is a time shift between the observed and simulated peaks. Therefore it is essential to develop irrigation scheduling strategies under local climatic conditions to utilize scarce water resources efficiently and effectively for crop production.
\end{abstract}

\section{Keywords}

Water Use Efficiency, Scheduling, Water Requirement, Climate Model

\section{Introduction}

Water is the major limiting factor for crop diversification and production. More than $80 \%$ of water resources have been exploited for agricultural irrigation [1]. 
To cope with the water-shortage, it is necessary to adopt water saving agriculture counter measures as efficient use of irrigation water is becoming increasingly important.

Irrigation consists of application of the right quantity or amount of water at the right time to the soil for plant growth. In actual fact the main essence of irrigation is to sometimes supplement natural rainfall in areas where the amount of rainfall is limited and erratic and this is referred to as supplemental irrigation. However, in desert areas where the soil is very fertile and can support crop productivity but there is very little or no rainfall at all, irrigation is therefore adopted [2]. This type of irrigation is known as total irrigation [3]. Inadequate irrigation application results in crop water stress and yield reduction. Excess irrigation application can result in pollution of water sources due to the loss of plant nutrients through leaching, runoff, and soil erosion. Likely, the desired frequency of irrigation depends on factors such as soil texture, rooting pattern, topography, evapotranspiration (ET) rate, rainfall, and crop type and/or developmental stage [4].

Irrigation scheduling can increase net farm income in cabbage production. The potential returns of irrigation scheduling are derived from three factors: increase irrigation efficiency, reduced cost of irrigation and opportunity cost of water [5] [6]. Similarly other report revealed that adequate irrigation design, good irrigation management and scheduling have been recognized as keys to increasing cabbage production on a sustainable basis. As a result, scheduling irrigation according to crop water needs minimises the chances of under or over watering [7]. Likewise there is less crop failure and leaching of fertilisers beyond the root-zone, and more profit for growers under well established crop water requirement reference [8]. Therefore, the aim of this review paper is to combine different information on cabbage water requirement, irrigation schedules and water use efficiency by triangulating different literatures on the topic.

\section{Water Requirement of Cabbage}

Cabbage has been classified as intermediately susceptible to water stress, with the head formation period being more sensitive than the period before [8]. The works of these authors were in line with [9] which were reported that the most critical irrigation period for cabbage occurred during the last 3 to 4 weeks before harvest. Marketable yields of cabbage were similar when irrigations were applied at $100 \mathrm{kPa}$ soil water tensions during growth and when cabbage was irrigated at $1000 \mathrm{kPa}$ before head formation and $100 \mathrm{kPa}$ after head formation. However, when cabbage was irrigated at $100 \mathrm{kPa}$ before head formation and at $1000 \mathrm{kPa}$ after head formation, marketable yields were similar to cabbage irrigated at 1000 $\mathrm{kPa}$ soil water tension during growth [10]. Yields of cabbage produced during the winter in Texas were similar when irrigated at $80 \mathrm{kPa}$ and $160 \mathrm{kPa}$ soil water tensions, but irrigating at a soil water tension of $360 \mathrm{kPa}$ reduced yields (40). Evapotranspiration (ETc) and cabbage water requirement for varied from 0.7 to 7.4 and from 28.2 to $40.9 \mathrm{~mm}$ /day respectively [8]. 
In order to obtain optimum cabbage yield and also allocate limited water resources suitably, and cabbage should be irrigated daily and in the evening [11]. This means that in order to obtain higher yield in cabbage so as to achieve best weight of the heads, it is important that farmer's practice daily irrigation since cabbage requires an abundant and well-distributed water supply.

If available water supply is limited, early irrigations should not be practiced unless these can be continued until the end of the crop growing period. Water savings should preferably be made in the beginning of the crop growing period. Water deficit during head formation period leads to shriveled and malformed heads. Root depth can extend up to $0.5 \mathrm{~m}$ but under irrigation condition roots are mainly concentrated in the upper $0.3 \mathrm{~m}$ soil depth [12].

\section{Estimation of Water Requirement of Cabbage}

According to the report of [13] estimation of water requirements for cabbage would help farmers avoid water wasting and financial loss related to the traditional techniques. Improved water resources management would promote efficient agricultural production and environmental sustainability. Irrigation water requirements for cabbage grown at Niamey were simulated for 30 years from 1981 to 2010 over a growing season of 100 days (10 dekads). The average seasonal irrigation water requirements were 553, 596 and $713 \mathrm{~mm}$ for cabbage planted on the $1^{\text {st }}$ of October, the $11^{\text {th }}$ of November, and the $21^{\text {st }}$ of December respectively. In this study the seasonal irrigation water requirement remains constant for the first two planting scenarios but shows a slight decreasing trend for the third planting scenario. The late planting date requires a little more irrigation water for the whole season compared to the other two planting dates having similar water needs. According this author the seasonal irrigation requirements for cabbage were estimated $808 \mathrm{~mm}$ and increases by $7 \%$ at midcentury and $11 \%$ by end of the century from 1990 to 2010 using CROPWAT 8.0 model [14].

Paul, 2013 reported that the water requirement of the crop was computed on daily basis by using the following equation [15]

$$
V=E p \cdot K p \cdot K c \cdot S p \cdot S r \cdot W p
$$

whereas,

$V=$ Volume of water required (liter/day/plant)

$E p=$ Pan evaporation as measured by Class-A pan evaporimeter ( $\mathrm{mm} /$ day)

$K c=$ Crop co-efficient (co-efficient depends on crop growth stage)

$K p=$ Pan co-efficient

$S p=$ Plant to plant spacing $(\mathrm{m})$

$S r=$ Row to row spacing $(\mathrm{m})$

$W p=$ Fractional wetted area, which varies with different growth stage (0.3 to $1.0)$.

Climate models reproduce acceptably the unimodal and bimodal shapes of the annual variation of rainfall and temperature respectively; there is a time shift 
between the observed and simulated peaks [16]. They reported also some discrepancies in the magnitude between the measured and the simulated values, and differences between projected values from one model to another. That behavior made them recommend caution in the use of those models' outputs and encouraged more investigation [16]. According to the same report, the statistical downscaling of the models' outputs shows at the national level an increase in the annual mean maximum temperature of $2.3^{\circ} \mathrm{C}$ (based on the scenario B2) and $2.6^{\circ} \mathrm{C}$ (based on the scenario A2) for the 2020-2049 time horizon. Those annual temperature increases are $+2.1^{\circ} \mathrm{C},+2.2^{\circ} \mathrm{C},+0.8^{\circ} \mathrm{C},+2.5^{\circ} \mathrm{C}$ (scenario A2), and $+2.0^{\circ} \mathrm{C},+1.9^{\circ} \mathrm{C},+0.9^{\circ} \mathrm{C},+2.4^{\circ} \mathrm{C}$ (scenario B2) for MaïneSoroa, BirniN'Konni, Niamey, and Tahoua respectively in Niger.

Water balance simulations with DSSAT resulted in very low values of the crops irrigation water needs [1] compared to values found by field experiments and with consideration to the local evapotranspiration rate [3]. Thus underestimation of the irrigation requirements may be explained by the limitations of the DSSAT models to simulate properly the soil water balance parameters under severe environmental stress as reported previously and/or the low empirical soil hydraulic conductivity coefficients associated with those models leading to low root water uptake estimates [17] [18].

FAO's CROPWAT 8.0 model is a computer program for calculation of Crop water requirements and Irrigation requirements based on soil-climate-crop data. The program allows the development of irrigation schedule for different management conditions and the calculation of scheme water supply for different areas under different crops [19]. The feature of the program includes:

- Monthly, decade and daily input of climate data for calculation of ETo.

- Monthly and daily calculation of crop water requirements including crop coefficients

- Daily soil water balance

\section{Climate Data:}

Import data by using CLIMWAT2.0 FAO model, select near meteorology station.

- Average minimum and maximum temperature Celsius degrees monthly.

- Average Relative Humidity monthly, percentage.

- Average wind speed monthly, kilometer per day.

- Average sunshine hours/day.

- Average solar radiation monthly, mega joule per square meter $\mathrm{MJ} / \mathrm{m}^{2} /$ day.

- Average ETO monthly, millimeter per day $\mathrm{mm} /$ day.

Rainfall Data:

Import rainfall and effect rainfall data by using CLIMWAT 2.0 FAO model

Soil Data:

Below, Import soil data by using FAO's Harmonized world soil database viewer 1.2 (HWSD) model, by including Longitude and latitude.

Optimal required water was determined as: $\mathrm{ET}_{\mathrm{c}}=\mathrm{Kc} \times \mathrm{ET}_{\mathrm{o}}$ where $\mathrm{Kc}$ is the crop coefficient and $\mathrm{ET}_{\mathrm{o}}$ is the reference evapotranspiration computed using a 
previous day's daily weather variables as inputs using the Penman-Monteith model [2]. The highest Kc values were found for mid-season, corresponding to the reproductive stage. As a result the largest water consumption is expected to occur during this stage [1]. Blanney-criddle method was used in the determination of crop evapotranspiration and reference evapotranspiration as well. $\mathrm{ET}_{\mathrm{c}}=$ $\mathrm{Kc} \times \mathrm{ET}_{\mathrm{o}}\left(\mathrm{mm} /\right.$ day) , where $\mathrm{Kc}$ is Crop co-efficient, $\mathrm{ET}_{\mathrm{o}}$ is Reference Evapotranspiration, Etc $=$ Crop Evapotranspiration. Then $\mathrm{ET}_{\mathrm{o}}$ calculate using the equation, $\mathrm{ET}_{\mathrm{o}}=\mathrm{P}(0.46 \mathrm{~T}+8)$, where $\mathrm{p}$ is 0.27 (mean monthly percentage day time hours which depends on the latitude) $\mathrm{T}=28.5^{\circ} \mathrm{F}$ (means monthly air temperature). Therefore, $\mathrm{ET}_{\mathrm{o}}=0.27\left(0.46 \times 28.5^{\circ}+8\right)=5.7 \mathrm{~mm} /$ day [20] $($ Table 1$)$.

The main shortcomings of irrigation models comprise a conceptual representation of the main irrigation system components-including the groundwater and drainage systems and their interactions [21].

\section{Irrigation Frequency for Cabbage Production}

According to the study carried out at Ghana Electricity Company's power house off Adaklu road in Ho using treatments (T1) was irrigated daily, (T2) was irrigated every three days, (T3) was irrigated once every week and (T4) was not under irrigation (Contol) the following result where obtained [20]. Similarly other author was concluded that frequency of irrigation of Chinese cabbage will depend on the type of soil. Sandy soil should be irrigated three times a week, sandy loam two times and clay or clay loam once a week. For a good-quality leaf harvest irrigates 51 of water per day for a plot size of $1 \times 1 \mathrm{~m}$. Irrigation should be done immediately after transplanting [22].

Irrigation frequency of cabbage varies between 3 and 12 days depends on climate, crop development and soil type. Similarly, Irrigation frequencies of 3 to 7 days interval are common, particularly in the early growth stages but at latter growth stages it might extend up to 7 to 12 days interval [14].

\section{Effects of Irrigation Frequency on Yield of Cabbage}

Different irrigation frequency differently influenced weight and number of cabbage at chikwawa, Malawi on experimental site gross plot $5 \mathrm{~m} \times 5 \mathrm{~m}$ and net plot $3 \mathrm{~m} \times 3 \mathrm{~m}$ whereas $0.6 \mathrm{~m}$ spacing between rows and between plants with in the rows were used. The highest weight and number of marketable heads were observed when irrigation frequency is twice a week [14] (Table 2).

Whereas study carried out at Thulamela Municipality, Vhembe District,

Table 1. Cabbage crop water requirement in $\mathrm{mm} /$ day.

\begin{tabular}{ccccc}
\hline Growth Stages (Days) & $\begin{array}{c}\text { Initial } \\
20-30\end{array}$ & $\begin{array}{c}\text { Development } \\
30-35\end{array}$ & $\begin{array}{c}\text { Mid-season } \\
20-30\end{array}$ & $\begin{array}{c}\text { Late-season } \\
10-20\end{array}$ \\
\hline Kc & 0.45 & 0.75 & 1.02 & 0.95 \\
$\mathrm{ET}_{\mathrm{o}}(\mathrm{mm} /$ day) & 5.7 & 5.7 & 5.7 & 5.7 \\
$\mathrm{ET}_{\mathrm{c}}(\mathrm{mm} /$ day $)$ & 2.57 & 4.28 & 5.81 & 5.42 \\
\hline
\end{tabular}

Source: [20]. 
Table 2. Effect of irrigation frequency on the yield of cabbage.

\begin{tabular}{ccccc}
\hline \multirow{2}{*}{$\begin{array}{c}\text { Irrigation } \\
\text { frequency }\end{array}$} & \multicolumn{2}{c}{ Weight of marketable heads $(\mathrm{t} / \mathrm{ha})$} & \multicolumn{2}{c}{$\begin{array}{c}\text { Number of harvested marketable } \\
\text { heads per frequency }\end{array}$} \\
\cline { 2 - 5 } & kasinthula & masenjere & kasinthula & masenjere \\
\hline Twice a week & 15 & 50.7 & 7037 & 22,778 \\
Once in week & 12.3 & 46.8 & 5926 & 18,333 \\
One in 14 days & 8.9 & 36.6 & 5648 & 18,241 \\
\hline
\end{tabular}

Source: [14].

Limpopo Province, South Africa presents the yield of fresh marketable leaves of non heading Chinese cabbage and total consumptive water use obtained in the five irrigation scheduling treatments. Irrigation scheduling practice affected both total consumptive water use and yield. The highest yields were obtained in the full irrigation (FI) and double frequency farmer (DFF) treatments, which also recorded the highest consumptive water use. The yields obtained in these two treatments (39 thha ${ }^{-1}$ in FI and $38 \mathrm{t} \cdot \mathrm{ha}^{-1}$ in DFF) were somewhat higher than the $30 \mathrm{t} \cdot \mathrm{ha}^{-1}$ Tindall, 1983 reported to be the upper limit of the yield obtained by farmers elsewhere in the world, suggesting that conditions in the FI and DFF treatments were very favourable. The minimal irrigation (MI) and farmer (F) treatments produced the lowest yields and total consumptive water use [23] (Table 3).

Irrigation applied after every 2 days interval from 20 days after complete germination was found most beneficial to increase vegetative growth in cabbage [10]. Similar results were obtained at brinjal, that the shorter the irrigation interval, the better was the plant growth. Whereas authors were concluded that irrigation on every 5 days throughout the cropping season of brinjal was most beneficial in increasing vegetative growth and yield. Grew cabbage in green house and irrigated at 4 levels of constant water regimes (from 100 - 80 to $40 \%$ $20 \%$ of full field capacity) and found that total dry matter, plant height and watering levels were positively related [24] [25].

Other studies which were concentrated on effect of frequency and quality of irrigation on growth and yield of cabbage with two irrigation intervals ( 1 and 3 days) and 3 application rates (3, 6 and $9 \mathrm{~mm}$ days $\left.^{-1}\right)$ of trickle irrigation were studied. Head weight, head diameter and leaf weight were increased significantly with increasing application rate from 3 to $6 \mathrm{~mm} /$ day whereas, with $9 \mathrm{~mm}$ days $^{-1}$ yield was maximized. Irrigation frequency and its interaction with quantity had no significant effect on the growth and yield [26].

Effect of irrigation at 3 and 7 days intervals on growth and yield of cabbage increased the yield from $20.9 \mathrm{t} \cdot \mathrm{ha}^{-1}$ controls to 34.1 and $40.6 \mathrm{t} \cdot \mathrm{ha}^{-1}$ at 7 and 3 days interval, respectively. The results indicated that cabbage required a soil moisture content of at least 70.0 per cent of available soil water in the top $12 \mathrm{~cm}$ for good yield and less than half the amount of water with mulching than without mulching [27].

Experiment on cabbage investigated the effect of four irrigation levels 0.50, 
Table 3. Effect of irrigation scheduling practice on the yield of fresh marketable leaves, consumptive water use and net contribution of stored soil water to total consumptive water use of non-heading Chinese cabbage (Brassica rapa subsp. chinensis).

\begin{tabular}{cccc}
\hline Treatment & $\begin{array}{c}\text { Yield of fresh } \\
\text { marketable } \\
\text { yield }\left(\mathrm{kg} / \mathrm{m}^{2}\right)\end{array}$ & $\begin{array}{c}\text { Total consumptive } \\
\text { water use }(\mathrm{mm})\end{array}$ & $\begin{array}{c}\text { Net contribution of stored soil } \\
\text { water to total consumptive } \\
\text { water use }(\mathrm{mm})\end{array}$ \\
\hline FI & 3.907 & 301 & 11 \\
MI & 2.310 & 176 & 57 \\
F & 2.644 & 192 & -19 \\
DFF & 3.815 & 302 & -29 \\
CF & 3.156 & 247 & 36 \\
\hline
\end{tabular}

$\mathrm{FI}=$ full irrigation $; \mathrm{MI}=$ minimal irrigation $; \mathrm{F}=$ farmer $\mathrm{DFF}=$ double frequency farmer; and $\mathrm{CF}=$ charged farmer. Source: [24].

0.75, 1.00 and 1.25 ID/CPE (irrigation depth $(\mathrm{mm}) /$ cumulative pan evaporation and three nitrogen levels at 50, 100 and $150 \mathrm{~kg} \mathrm{~N} \mathrm{ha}^{-1}$ ). The yield was increased with rising nitrogen and irrigation levels to a maximum at $150 \mathrm{~kg} \mathrm{~N} \mathrm{ha}^{-1}$ and irrigation at $1.25 \mathrm{ID} / \mathrm{CPE}$, respectively [11].

\section{Water Use Efficiency of Cabbage}

The average irrigation water needs for cabbage at Niamey is $6 \mathrm{~mm} /$ day. Therefore, by assuming an irrigation efficiency of $75 \%$, the gross irrigation water needs will be $8 \mathrm{~mm} /$ day. These irrigation rates are assumed to be sufficient not only for crop production but also to prevent eventual salinization of the soil. The validity of this assumption depends on local soil and water conditions [1]. In addition about $97 \%$ of water taken up by cabbage plant is lost to the atmosphere, $2 \%$ is used for volume increase or cell expansion, and $1 \%$ for metabolic processes, predominantly photosynthesis. Water loss to the atmosphere appears to be an inevitable consequence of carrying out photosynthesis [18]. Crop water use efficiency (WUE) can be increased either by enhancing crop transpiration or by plant breeding to produce greater biomass $\left(\mathrm{CO}_{2}\right.$ assimilation) and yield per unit of water used. The uptake of $\mathrm{CO}_{2}$ is coupled to the loss of water. Because the driving gradient for water loss from leaves is much larger than that for $\mathrm{CO}_{2}$ uptake, as many as 400 water molecules are lost for every $\mathrm{CO}_{2}$ molecule gained whereas dehydration avoidance as achieved by enhanced capture of soil moisture by roots associated with low WUE [19] [28].

Climate change poses significant challenges to agriculture due to increased temperatures, droughts and water scarcity, but it also provides opportunities to improve crop yields in arid and semiarid zones. Yield of water-limited crops is determined by crop water use and WUE, both of which can be affected by the increase in atmospheric carbon dioxide $\left(\mathrm{CO}_{2}\right)$ and temperature. At leaf level, the increase in transpiration efficiency may result both from an increase in photosynthetic rate and a decrease in stomatal conductance. WUE can be maximized by applying deficit irrigation, irrigation technology and irrigation scheduling as well as by improving agricultural practices that can result in the increase of crop 
yields. Drip irrigation is the response to pressure on limited fresh-water resources and plays an important role in the increase of WUE. Nevertheless, there is still limited information on how to use it on conventional crops. But WUE increased from $4.15 \mathrm{~kg} \cdot \mathrm{m}^{-3}$ with furrow irrigation to $8.2 \mathrm{~kg} \cdot \mathrm{m}^{-3}$ with drip irrigation in a cabbage crop [13] [29].

Cabbages need regular irrigation to ensure rapid growth and evenness of maturity. They can be irrigated by moveable spray lines, travelling irrigators or solid set, or, if the soil is suitable and water available, flood irrigation might be more productive. Likewise, cabbages grown in beds will require more irrigation than those grown on the flat. On other hand soil type and weather will also influence the frequency of irrigation. Thus, the use of tensiometers or other measuring equipment will improve yields and reduce water costs [30].

Optimum yield of cabbage the soil water depletion in most climates should not exceed $30 \%$ to $35 \%$ of the total available soil water. Due to this light irrigation applications are recommended. Therefore, in their experiment studied the effects of varying water supply on the water regime and productivity of head cabbage. He carried out container and field trials with mid early and mid late cabbage cultivars using sprinkler irrigation to maintain field water capacity at 80 per cent which resulted in highest yield [31].

Irrigation plots develop a response curve relating to cabbage yield in coarse sandy soils. The daily replacement of 120 to 150 per cent of pan evaporation maximized the yield of crops, harvested during the late summer and early autumn. Over watering and too frequent watering reduced the yield [32]. In addition to this other authors studied on deficit irrigation effect on head of cabbage production. In the experiment, yield response of head cabbage to 10 different trickle irrigation rates $\left(0.42-1.94 \mathrm{~mm} \mathrm{day}^{-1}\right)$ was studied during 1983-87 at kula, Hawaii. The marketable yield increased linearly with increasing water application. The relationship between relative yield and relative evapo-transpiration was linear with a response coefficient of 0.95 [33].

\section{Effect of Moisture Regime on Cabbage Production}

It is essential to develop irrigation scheduling strategies under local climatic conditions to utilize scarce water resources efficiently and effectively. Frequency of watering depends on many things. A large plant needs more water than a small plant. A shallow-rooted vegetable (cabbage, onion, lettuce, corn) needs to be irrigated more often than a deep-rooted vegetable (asparagus, tomato, watermelon). Coarse textured soils (sandy loams) need to be irrigated more often than fine-textured (clay or silt loams). Plants need to be watered more often during hot periods than cool periods. In an average situation during warm weather, a good soaking of the soil every 5 to 7 days should give satisfactory results with established plants [34].

Other studies have done on the effect of irrigation and mulch on the growth and yield of cabbage in the hilly regions. Mulched and non-mulched plant were irrigated with $90.42,113.82,139.52,161.72,209.37 \mathrm{~mm}$ water $\mathrm{ha}^{-1}$. The plant 
growth and yield increased with increasing irrigation rates from $29.8 \mathrm{t} / \mathrm{ha}$ at $90.42 \mathrm{~mm} \cdot \mathrm{ha}^{-1}$ to $47.9 \mathrm{t} \cdot \mathrm{ha}^{-1}$ at $209.37 \mathrm{~mm} \cdot \mathrm{ha}^{-1}$. However, in the presence of mulch the maximum growth and yield were obtained with irrigation at 161.72 $\mathrm{mm} \cdot \mathrm{ha}^{-1}[35]$.

\section{Conclusion}

Water requirement of cabbage varies with climate, soil type, crop variety and management practices. On sandy soil frequent application of cabbage is highly productive in comparison to clay soil. This is because of down word and lateral movement of soil water is prevailed in sandy and clay soil respectively. Thus yield and water use efficiency of irrigated cabbage generally increased with increasing levels of management options. As a result, crop water requirement is inclusive to crop modeling strategies which are proactive to sustainable agriculture particularly in the view of climate change. Therefore, crop production should be supported by prediction data.

\section{References}

[1] Sitta, A. (2011) Optimizing Irrigated Horticulture and Prediction of Climate Change Impacts by Crop Modeling for Niger. MSc. Thesis, Faculty of the Graduate College of the Oklahoma State University, Niger.

[2] Asare, D.K., Tawiah, I.L., Frimpong, J.O., Yaro, M., Banson, K., Ayeh, E.O. and Heng, L.K. (2012) Yield, Water and Nitrogen Use by Drip-Irrigated Cabbage Grown Under Different Levels of Applied Water. IAEA-CN-191-14.

[3] Lenart, M. (2008) Climate Downscaling Techniques. The University of Arizona. Retrieved in November 2011.

[4] Hanson, B.R., May, D.M. and Schwankl, L.J. (2003) Effect of Irrigation Frequency on Subsurface Drip Irrigated Vegetables. Department of Land, Air and Water Resources, University of California, Davis, CA.

[5] English, M.J., Musich, J.T. and Murty, V.V.N. (1990) Deficit Irrigation. In: Hoffman, G.J., Howell, T.A. and Solomon, K.H., Eds., Management of Farm Irrigation Systems, ASAE, ASAE, St. Joseph, MI.

[6] Fardad, H. and Golgar, H. (2002) An Economic Evaluation of Deficit Irrigation on Wheat Yield in Karaj. Iranian Journal of Agricultural Sciences, 33, 305-312.

[7] Qassim, A. and Ashcroft, B. (2012) Estimating Vegetable Crop Water Use. Agriculture Information, DEPI, Victoria.

[8] Adeniran, K.A., Amodu, M.F., Amodu, M.O. and Adeniji, F.A. (2010) Water Requirements of Some Selected Crops in Kampe Dam Irrigation Project. AJAE, 1, 119-125.

[9] Thomas, J.R., Namken, L.N. and Brown, R.G. (1970) Yield of Cabbage in Relation to Nitrogen and Water Supply. Journal of the American Society for Horticultural Science, 95, 732-735.

[10] Sharma, D. (1975) Water Relations of Radish (Raphanussativus L.) cv. Pusachetki. MSc. Thesis, Submitted to Faculty of Agriculture University of Udaipur, Rajasthan.

[11] Mangal, J.L., Pandita, M.L. and Batra, B.R. (1984) Effect of Irrigation Intensities and Nitrogen Levels on Growth and Yield of Cabbage (Brassica oleracea var. capitata) cv. Golden Acre. Haryana Journal of Horticultural Sciences, 11, 92-96.

[12] Miller, D.G., Manning, C.E. and Teare, I.D. (1977) Effects of Soil Water Levels on 
Components of Growth and Yield in Peas. Journal of American Society of Horticulture Science, 102, 349-351.

[13] Hassanli, A.M., Ahmadirad, S. and Beecham, S. (2010) Evaluation of the Influence of Irrigation Methods and Water Quality on Sugar Beet Yield and Water Use Efficiency. Agricultural Water Management, 97, 357-362.

[14] Chafutsa, W., Fandika, I.R., Kadympakeni, D.M., Chiipanthenga, H.M. and Mafunga, G. (2007) Comparative Study of Cabbage to Tea Ferilizer, Compost Manure and Inorganic Fertilizer under Furrow irrigation. Irrigation Drainage Team, Kasinthula Agricultural Experiment Station, Chikwawa.

[15] Shukla, K.N., Singh, P.K. and Singh, K.K. (2001) Crop Water Requirement under Drip Irrigation. Plasticulture Development Centre, GBPUAT, Pantnagar.

[16] CNEDD (2009) Niger Second National Communication on Climate Change. Conseil National de l'Environnement pour le Développement Durable, Niamey.

[17] De Faria, R.T. and Bowen, W.T. (2003) Evaluation of DSSAT Soil-Water Balance Module under Cropped and Bare Soil Conditions. Brazilian Archives of Biology and Technology, 46, 289-498. https://doi.org/10.1590/s1516-89132003000400001

[18] Dott. Agr. Ivan Solinas and Ammar Husham Jalal AL-Bayati (2014) Assessment of Water Requirement and Irrigation Scheduled by Using of Subsurface Drip Irrigation for Tomato (Solanaceae) with Support of FAO Cropwat in Abu Ghraib.

[19] Blum, A. (2005) Drought Resistance, Water-Use Efficiency, and Yield PotentialAre They Compatible, Dissonant, or Mutually Exclusive? Australian Journal of Agricultural Research, 56, 1159-1169. https://doi.org/10.1071/AR05069

[20] Nyatuame, M., Ampiaw, F., Owusu-Gyimah, V. and Mabinde, B. (2013) Irrigation Scheduling and Water Use Efficiency on Cabbage Yield. Ghana Electricity Company's Power House Off, Adaklu.

[21] Nicolas, R. (2002) Improving Irrigation Water Use Efficiency, Productivity and Equity. Simulation Experiments in the Downstream Yellow River Basin. International Water Management Institute (IWMI), Colombo.

[22] Laker, M.C. (2007) Introduction to the Special Edition of Water SA on Indigenous Crops, Water and Human Nutrition. Water SA, Vol. 33, No. 3, Water Research Commission.

[23] Van Averbeke, W. and Netshithuthuni, C. (2010) Effect of Irrigation Scheduling on Leaf Yield of Nonheading Chinese Cabbage (Brassica rapa L. subsp. chinensis). South African Journal of Plant and Soil, 27, 322-327. https://doi.org/10.1080/02571862.2010.10640001

[24] Hafeez, A.T.A. and Cornllion, P. (1976) Effect of Irrigation Rhythm on Growth, Fruit Set, Yield and Quality of Egg Plant (Solanum melongena) in Southern France. Plant and Soil, 45, 213-225. https://doi.org/10.1007/BF00011143

[25] Patel, M.T. (1980) Response of Irrigation Regimes at Different Growth Stages and Gibberellic Acid Application on the Performance of Brinjal (Solanum melangena L.). M.Sc. Thesis, University of Udaipur.

[26] Rahman, H.A.A., Ibrahim, A.A. and Elias, S.A. (1994) Effect of Frequency and Quantity of Irrigation on Growth and Yield of Cabbage (Brassica oleracea L.). European Journal of Agronomy, 3, 249-252.

[27] Tumuhairwe, J.K. and Gumbs, F.A. (1983) Effect of Mulches and Irrigation on the Production of Cabbage (Brassica oleracea) in the Dry Season. Tropical Agriculture, 60, 122-127.

[28] Taiz, L. and Zeiger, E. (2010) Productivity of Various Ecosystems as a Function of Annual Precipitation. Plant Physiology, 68. 
[29] Wayne, P.H. (2002) Implications of Atmospheric and Climate Change for Crop Yield and Water Use Efficiency. Crop Science, 42, 131-139. https://doi.org/10.2135/cropsci2002.0131

[30] Murison, J. (2006) Cabbage Growing Prime Facts. Intensive Industries Development, Yanco.

[31] Gancharyk, M.M. and Paulenka, Z.R. (1975) The Effect of Varying Water Supply on the Water Regime and Productivity of Head Cabbage. BiyalagichnykhNavuk, 6, 11-17.

[32] Cripps, J.E.L., George, P.R. and Oakley, A.E. (1982) Scheduling Irrigation of Cabbage Using Pan Evaporation. Irrigation Science, 3, 185-195. https://doi.org/10.1007/BF00446007

[33] Sammis, T.W. and Wu, I.P. (1989) Deficit Irrigation Effects on Head Cabbage Production. Agricultural Water Management, 16, 229-239.

[34] Himanshu, S.K., Kumar, S., Kumar, D. and Mokhtar, A. (2012) Effects of Lateral Spacing and Irrigation Scheduling on Drip Irrigated Cabbage (Brassica Oleracea) in a Semi Arid Region of India. Research Journal of Engineering Sciences, 1, 1-6.

[35] Rahman, M.A., Guha, D., Golder, P.C. and Sattar, M.A. (1989) Effect of Irrigation and Mulch on the Growth and Yield of Cabbage in the Hilly Region. Bangladesh Horticulture, 17, 37-39.

Submit or recommend next manuscript to SCIRP and we will provide best service for you:

Accepting pre-submission inquiries through Email, Facebook, LinkedIn, Twitter, etc. A wide selection of journals (inclusive of 9 subjects, more than 200 journals) Providing 24-hour high-quality service User-friendly online submission system Fair and swift peer-review system Efficient typesetting and proofreading procedure Display of the result of downloads and visits, as well as the number of cited articles Maximum dissemination of your research work

Submit your manuscript at: http://papersubmission.scirp.org/

Or contact gep@scirp.org 